\title{
New taxa of Omalisidae, Drilidae and Omethidae, with a note on systematic position of Thilmaninae (Coleoptera)
}

\author{
Новые таксоны Omalisidae, Drilidae и Omethidae, с замечанием по \\ систематическому положению Thilmaninae (Coleoptera)
}

\author{
Sergey V. Kazantsev \\ С.В. Казанцев
}

Insect Centre, Donetskaya 13-326, Moscow 109651, Russiaş

Инсект-центр, ул. Донецкая 13-326, Москва 109651, Россия. E-mail: kazantss@mail.ru

KEY WORDS: Coleoptera, Omalisidae, Drilidae, Omethidae, new tribe, new genus, new species, taxonomy, Palaearctic.

КЛЮЧЕВЫЕ СЛОВА: Coleoptera, Omalisidae, Drilidae, Omethidae, новая триба, новый род, новые виды, таксономия, Палеарктика.

ABSTRACT. A new tribe, Euanomini tr.n., in Drilidae, and a new genus, Cimbrion gen.n., in Omalisidae, are erected and four new species, Euanoma argonauta, E. kolchica, Pseudeuanoma caligo spp.n. (all Drilidae) and Drilonius flavipennis sp.n. (Omethidae), are described, the drilids from Georgia and Turkey and the omethid from China. The subfamily Thilmaninae is transferred from Omalisidae to Drilidae. A complete check-list of the genera and species of the subfamily Thilmaninae that includes tribes Thilmanini and Euanomini tr.n. is provided.

РЕЗЮМЕ. Устанавливается новая триба, Euanomini tr.n., в Drilidae, и новый род Cimbrion gen.n., в Omalisidae, и описывается четыре новых вида, Euanoma argonauta, E. kolchica, Pseudeuanoma caligo spp.n. (все Drilidae) и Drilonius flavipennis sp.n. (Omethidae), дрилиды из Грузии и Турции, а ометид из Китая. Подсемейство Thilmaninae переносится из Omalisidae в Drilidae. Приводится полный список родов и видов подсемейства Thilmaninae, которое включает трибы Thilmanini и Euanomini tr.n.

\section{Introduction}

The families Omalisidae, Drilidae and Omethidae are typically considered to belong to the somewhat vaguely delineated superfamily Cantharoidea, although some scholars contend that all of them make part of a larger superfamily Elateroidea [e.g., Lawrence \& Newton, 1982], while others argue that such lumping contradicts to the available morphological data [e.g., Dolin, 2000]. Drilidae and Omethidae are represented by a relatively large number of genus group taxa distributed in several biogeographical regions, whereas the only two known omalisid genera, Omalisus Geoffroy, 1762 and Phaeopteris A. Costa, 1857 (the also Mediterranean Thilmanus Gemminger, 1869 is hereby excluded from Omalisidae), are confined to Central and Southern Europe. The females are known only in one omalisid, Omalisus fontisbellaquaei Geoffroy, 1785, and by very few specimens [Geisthardt, 1977].

The genera Euanoma Reitter, 1889 and Pseudeuanoma Pic, 1901 initially classified in Omalisidae were tentatively transferred to Drilidae by Crowson [1972] and Medvedev \& Kazantsev [1992], the authors stating that the relationships between the two families are not clear and need further study. A later examination of morphology of the type species of Euanoma, in comparison with the type species of the type genera of Omalisidae and Drilidae, allowed establishing the hypothetic autapomorphies of Omalisidae and Drilidae and confirmed that Euanoma, along with Pseudeuanoma, must be attributed to Drilidae [Kazantsev, 2008]. Additionally, the Omalisidae and the drilid genera Euanoma and Pseudeuanoma were revised by Kundrata \& Bocák [2007] and Bocák \& Brlik [2008]. The positive side of these revisions was that all types of the rare and little known species were studied and illustrated, while the negative side was that the taxa were classified in Omalisidae or Drilidae almost solely on the basis of the male genital structures, with many other taxonomically important morphologies ignored or neglected. As a result, certain indisputable omalisids were transferred to Drilidae, the genus Euanoma becoming a welter of very unlike and little-related species, and the apparently alien Thilmanus, on the contrary, was included in Omalisidae.

A careful re-examination of representatives of these families allows placing some of the taxa more properly. It also necessitates erecting a new genus in Omalisidae and a new tribe in Drilidae. Additional new species 
discovered in the genera Euanoma and Pseudeuano$m a$ and in the omethid genus Drilonius Kiesenwetter, 1874 are described.

The following acronyms are used in this paper: ICM — Insect Center, Moscow; ZIN — Zoological Institute of the Russian Academy of Sciences, S-Petersburg; ZMMU — Zoological Museum of Moscow University.

\section{Material and Methods}

After being relaxed in water abdomens of specimens of the studied species were kept for several hours in room temperature $10 \% \mathrm{KOH}$. The aedeagi and the ultimate abdominal segments were then placed in microvials with glycerin.

\section{Taxonomy}

\section{Family OMALISIDAE}

\section{Cimbrion Kazantsev gen.n.}

Type species: Phaeopterus nigricornis Reitter, 1881.

DESCRIPTION. Male. Elongate. Head transverse. Fastigium acute. Labrum subquadrate. Eyes moderately large, spherical. Mandibles small, evenly curved. Maxillary and labial palps slender, with ultimate palpomeres relatively large and obliquely cut distally. Gena transverse, trapezoidal. Antennal prominence conspicuous, antennal sockets separated by ca. socket's diameter. Antennae 11-segmented, relatively short, hardly attaining to elytral middle, filiform (Fig. 1); antennomeres 2 and 3 subequal in length and combined slightly longer than antennomere 2 and slightly shorter than scapus (Fig. 3); pubescence of antennomeres 1-11 uniform, moderately long and decumbent.
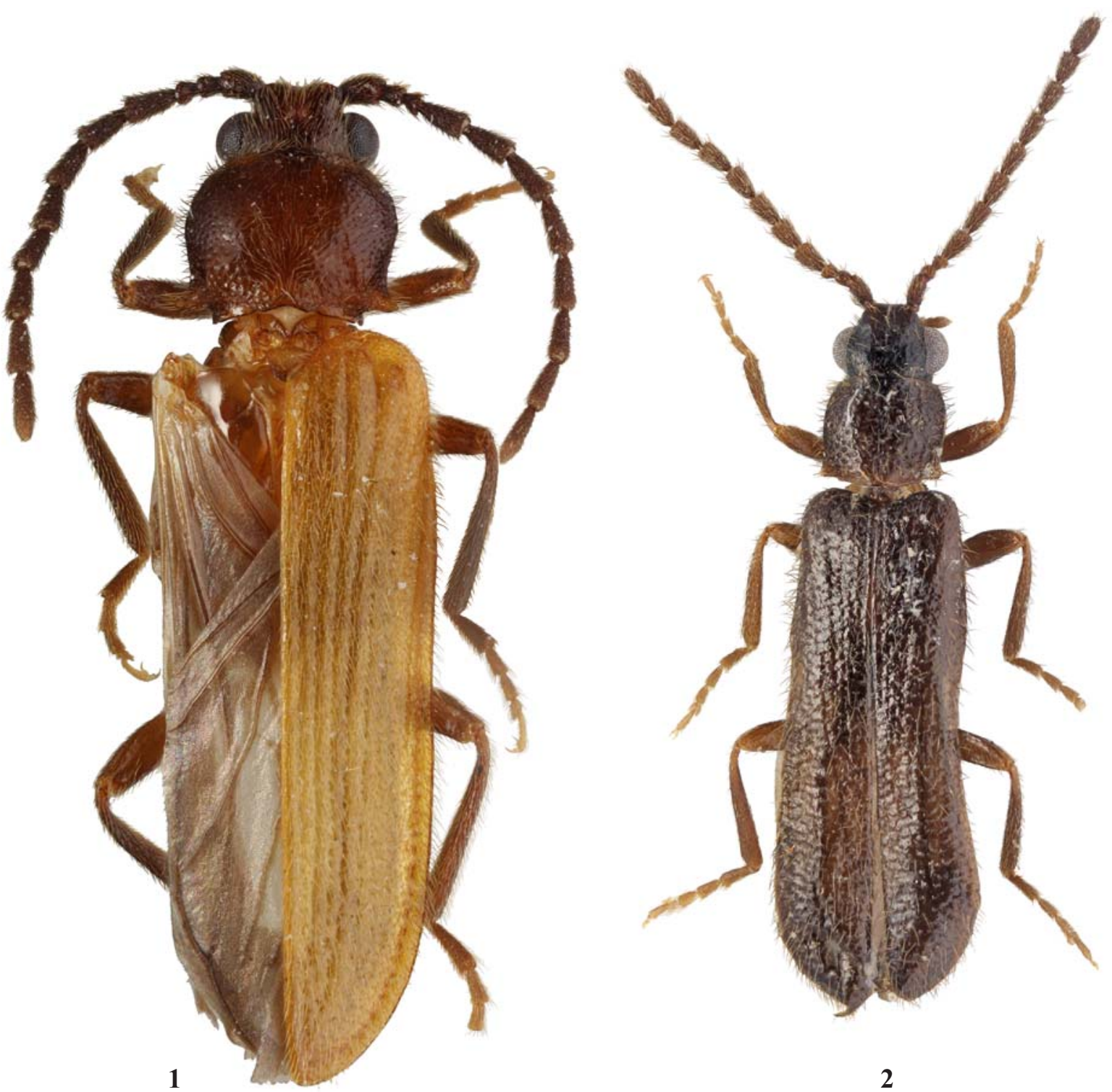

Figs 1-2. General view of Omalisidae and Drilidae, males: 1 - Cimbrion nigricorne; 2 - Pseudeuanoma caligo sp.n.; 2 - holotype. Рис. 1-2. Общий вид самцов Omalisidae и Drilidae: 1 - Cimbrion nigricorne; 2 - Pseudeuanoma caligo sp.n.; 2 - голотип. 


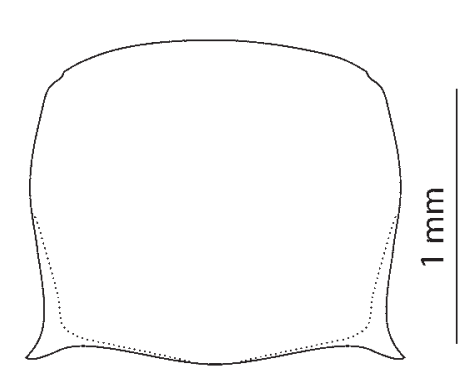

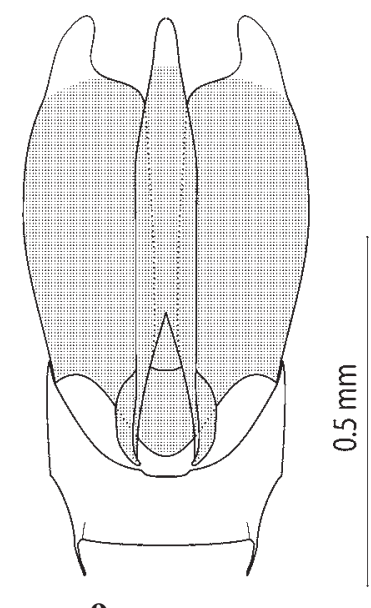

9

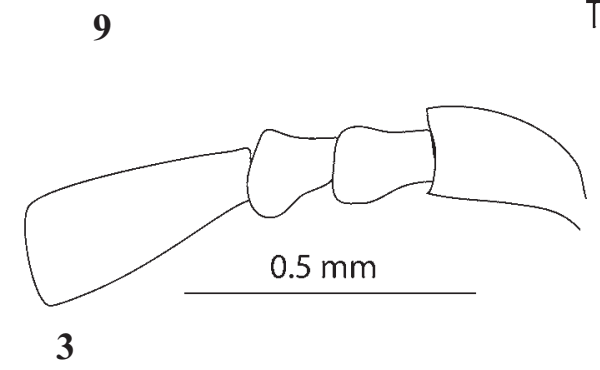

3

8

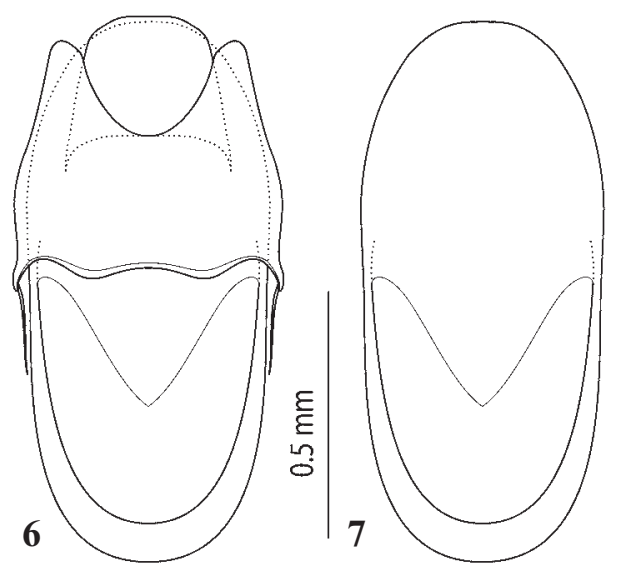

$\mathrm{T} 10$
5

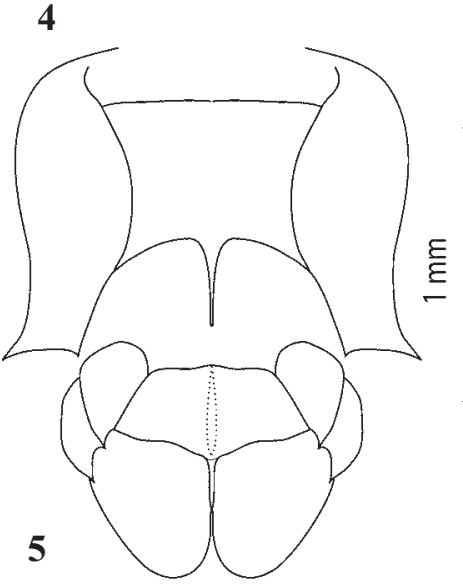

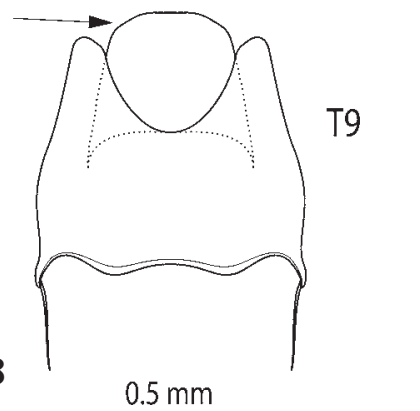

Figs 3-9. Details of Cimbrion nigricorne, male: 3 - antennomeres 1-4; 4 - pronotum; 5 — pro- and mesosternum; 6 - genital capsule; 7 - ultimate ventrite (ventrite 6 ); 8 - ultimate tergites; 9 - aedeagus; 7,9 - ventral view; 4, 6, 8 - dorsal view; $T$ - tergite.

Рис. 3-9. Детали строения Cimbrion nigricorne, самца: 3 - антенномеры 1-4; 4 - переднеспинка; 5 - передне- и среднегрудь; 6 генитальная капсула; 7 - вершинный вентрит (вентрит 6); 8 - вершинные тергиты; 9 — эдеагус; 7,9-снизу; 4, 6, 8- сверху; $T$ - тергит.

Pronotum slightly wider than long, almost straight anteriorly, with acute, produced latero-posteriorly posterior angles (Fig. 4), gently punctured at disk and more coarsely punctured at sides. Prosternum elongate, with straight anterior and posterior margins, concave at sides, with long posterior median process (Fig. 5). Mesothoracic spiracles small. Mesosternum transverse, with straight anterior margin (Fig. 5). Mesepimeron relatively wide and only slightly shorter than mesepisternum (Fig. 5). Postnotal plate of scutellum small, triangular, rounded at apex. Elytra long, parallel-sided, jointly rounded at apices, with eight longitudinal rows of shallow punctures and inconspicuous costae; sub-erect pubescence relatively long. Discrimen (metasternal suture) complete. Metathoracic wing $\mathrm{Cu}$ veins connected to $\mathrm{M}$; wedge cell absent; cu-a brace long above $\mathrm{Cu}$ veins fork.

Mesocoxae subquadrate, approximate. Legs moderately long; trochanters elongate, distally oblique; tibiae straight, considerably narrower than femurs, with pair of minute spurs. Tarsomeres narrow, not lobed, without plantar pads; all claws simple. Abdomen with six ventrites; genital capsule consisting of ventrite 6 and tergites 9 and 10 (Figs 6-8). Abdominal spiracles located dorsally on membrane. Aedeagus trilobe, with straight median lobe and flattened parameres; phallobase with latero-proximal apodemes (Fig. 9).

Female. Unknown.

DIAGNOSIS. Cimbrion gen.n. is readily distinguishable from Omalisus and Phaeopteris, the other two omalisid genera, by the absence of prominent elytral costae and by the absence of a keel parallel to the lateral pronotal margin (these characters made Bocák \& Brlik [2008] transfer Phaeopterus nigricornis, the type species of Cimbrion gen.n., to Euanoma in Drilidae). It also has one abdominal ventrite less than Omalisus or Phaeopteris. It differs from Euanoma and other drilids by the elongate prosternum with a long posterior median process (Fig. 5) and by the strongly sclerotized elytra coadapted both with the thorax and abdomen, with conspicuous epipleuron attaining to elytral apices and complete sclerotized flange at suture, i.e., by characters that were hypothesized to be autapomorphies of Omalisidae [Kazantsev, 2008]. It has a straight anterior margin of the mesosternum and relatively short mesepimeron (Fig. 5), which are also characteristic of omalisids [Kazantsev, 2008].

ETYMOLOGY. The name is derived from "the Cimbri", the name of a people that invaded Italy and other possessions of Rome in southern Europe over two thousand years ago, but vanished before the $2^{\text {nd }}$ century AD. Gender neutral.

BIOLOGY. No biological data on Cimbrion gen.n. is available. Females probably larviform.

DISTRIBUTION. Balkan Peninsula (Croatia and Bosnia). So far only one species is classified in Cimbrion gen.n., but it is possible that Euanoma graeca (Pic, 1901), described from Greece as Phaeopterus and transferred to Euanoma by Kundrata \& Bocák [2007], may prove to be another member of this genus.

\section{Cimbrion nigricorne (Reitter, 1881) comb.n.} (Figs 1, 3-9)

Phaeopterus nigricornis Reitter, 1881: 220.

Euanoma nigricornis (Reitter): Bocák \& Brlik, 2008: 210.

$=$ Homalisus flavangulus Spaeth, 1898: 857.

MATERIAL. O", [Croatia]: "Dalmatia, Biokovo-Gb.", "Homalisus flavangulus" (ZIN).

DISTRIBUTION. Balkan Peninsula (Croatia and Bosnia). 
REMARKS. The aedeagus of Cimbrion nigricorne (Reitter, 1881) comb.n. illustrated by Bocák \& Brlik [2008] appears to be damaged (maybe due to $\mathrm{KOH}$ boiling), or taken from a specimen affected by teratology. Only eight specimens of this genus are known, including one listed above, apparently none collected after the turn of the 20 th century.

\section{FamilyDRILIDAE}

\section{Subfamily THILMANINAE Kazantsev, 2005}

Type genus: Thilmanus Gemminger, 1869.

DIAGNOSIS. Thilmaninae is readily distinguishable from the nominative subfamily, Drilinae, by the narrow body (Figs 2,10 ), simple mandibles, presence of a coronal suture (Figs 11,22 ), protrochantin separated from cryptopleuron by sutures, divided by a median suture mesoventrite with almost straight anterior margin (Figs 14, 23), small posterior process of the postnotal plate of the mesoscutellum (Figs 15, 24), hind wing with $\mathrm{Cu}$ veins connected at least to A veins (Figs $16,26)$, straight connection of pro- and mesotrochanters (Figs 17, 27) and presence of latero-proximal apodemes of the phallobase (e.g., Figs 20-21, 31-32).

REMARKS. Thilmanus, initially associated with omalisids, has had a rich history of transfers. First Crowson [1972] transfered it to Lycidae on the basis of its straight anterior mesosternal margin and elongate trochanters; then it was returned to Omalisidae as it has "similar male genitalia" [Bocák \& Bocáková, 1990]; shortly afterwards it is classified in Drilidae as possessing sclerotized tentorium and elytral epipleura at humeri [Medvedev \& Kazantsev, 1992]; then it is excluded from Drilidae due to the numerous morphologies separating them and placed in Lycidae as a new subfamily [Kazantsev, 2005]; finally, it is returned to Omalisidae as having, again, "similar male genitalia" and "sharing with Phaeopterus the parameres without outwardly hooked apices and the shape of the basal antennomeres" [Bocák \& Brlik, 2008].

Evidently, the latter transfer was the least substantiated. Many members of a number of beetle families, e.g., the drilid genera Euanoma and Pseudeuanoma, would thus fit in Omalisidae. As the autapomorphies of Omalisidae had already been delineated [Kazantsev, 2008], including here Thilmanus, which does not share the mentioned apomorphic characters with omalisids, on the basis of an apparent symplesiomorphy (the latero-proximal apodemes of the phallobase manifest in both Omalisidae and Drilidae) [Bocák \& Brlik, 2008], appears to be hardly consistent with principles of systematics.

The differencies of Thilmanus as compared to Omalisus are as follows: the tentorium reduced to a pair of slender ventral arms (Fig. 12) vs. robust tentorium with conspicuous tentorial bridge; absent posterior median process of prosternum (Fig. 14) vs. elongate posterior median prosternal process (e.g., Fig. 5); straight posterior margin of mesosternum (Fig. 14) vs. angular posterior mesosternal margin; elongate mesepimeron (Fig. 14) vs. short and transverse mesepimeron; soft elytra non-coadapted with thorax and abdomen, with inconspicuous epipleuron only at elytral humeri and absent flange at suture vs. heavily sclerotized elytra coadapted both with thorax and abdomen, with conspicuous epipleuron attaining to elytral apices and complete sclerotized flange at suture; hind wing with anal lobe and cubital cell (Fig. 16) vs. absent anal lobe and no cubital cell; genital capsule consisting of two tergites and one sternite, penultimate tergite and ultimate sternite not fused (Figs 18-19) vs. genital capsule consisting of three tergites and two sternites, penultimate tergite and ultimate sternite proximally fused (Figs 48-51) [other Omalisus structures illustrated in Kazantsev, 2008].
Unfortunately, Bocák \& Brlik [2008], stating that Thilmanus is close to Phaeopterus, gave actually no details on Phaeopterus morphology other than illustrating its aedeagus and provided no data on the structures that separate Thilmanus and omalisids. If Phaeopterus were indeed close to Thilmanus, it would exclude Phaeopterus from Omalisidae and bring it to Thilmaninae. While some of the more archaic conditions of the characters separating Thilmanus and Omalisus could be considered possible plesiomorphies of the hypothetic lineage Omalisidae + Thilmaninae, such characters as the structure of the tentorium and elytra, which are fundamentally different, do not allow regarding them as a single higher level taxon.

The differencies between Thilmanus and Lycidae are fewer than between the former and omalisids or drilids and include the seven male abdominal ventrites, rectangular prosternum (Fig. 14), medially divided mesoventrite (Fig. 14) and the hind wing with anal lobe and cubital cell (Fig. 16) in Thilmanus vs. eight male ventrites, V-shaped, triangular or diamond-shaped prosternum, undivided mesoventrite and absent anal lobe and cubital cell in the hind wing in the Lycidae. As for the number of abdominal segments visible ventrally, it often varies in Cantharoidea taxa not affecting their affinities with the families - in Cantharidae, for instance, the number of male abdominal ventrites ranges from 7 to 10 . The structure of the mesoventrite in Thilmanus may represent a plesiomorphy, so the presence of a median suture does not necessarily exclude the taxon from the family; besides, a medially divided mesoventrite has been discovered in Cessator Kazantsev, 2009, one of the Greater Antillean lycids [Kazantsev, 2009]. Similarly, the anal lobe of the hind wing, not matched elsewhere in the superfamily, may be yet another plesiomorphy. However, the rectangular shape of the prosternum does not seem to represent a plesiomorphy in a lineage containing Lycidae. Regarding it an autapomorphy of Thilmaninae (and including the taxon in Lycidae) would indeed make the rest of the lycids shrink to, technically, a single very heterogenous subfamily.

On the other hand, characters separating Thilmanus and Drilus G.A. Olivier, 1790 - the simple mandibles and evident coronal suture (Fig. 11) vs. dentate mandibles and absent coronal suture; protrochantin separated from cryptopleuron by sutures (Fig. 14) vs. protrochantin fused with cryptopleuron; small posterior process of mesonotal scutellum (Fig. 14) vs. large posterior process of the mesonotal scutellum; mesoventrite divided by median suture (Figs 14) vs. simple mesoventrite; hind wing with $\mathrm{Cu}$ veins connected to A veins (Fig. 16) vs. $\mathrm{Cu}$ veins connected neither to $\mathrm{M}$ nor to A veins; right connection to femurs of elongate pro- and mesotrochanters (Fig. 17) vs. obliquely connected short trochanters; latero-proximal apodemes of the phallobase (Figs 20-21) vs. absence thereof - though great enough, seem to conflict less with uniting the two genera in a single higher level taxon, as most of the presumably archaic conditions of the characters, be it in Thilmanus or Drilus, could be regarded as possible symplesiomorphies of the hypothetic lineage.

On the strength of the above considerations, Thilmanus is excluded from Omalisidae and placed in Drilidae in the subfamily Thilmaninae. As most important characters distinguishing Thilmanus from Drilus are shared by Euanoma [Kazantsev, 2008], the latter genus, along with Pseudeuano$m a$, is also attributed to Thilmaninae in Euanomini tr.n.

DISTRIBUTION. The two tribes included in Thilmaninae, Thilmanini and Euanomini tr.n., are confined to the Central (Thilmanini) and Eastern (Euanomini tr.n.) Mediterranean. 


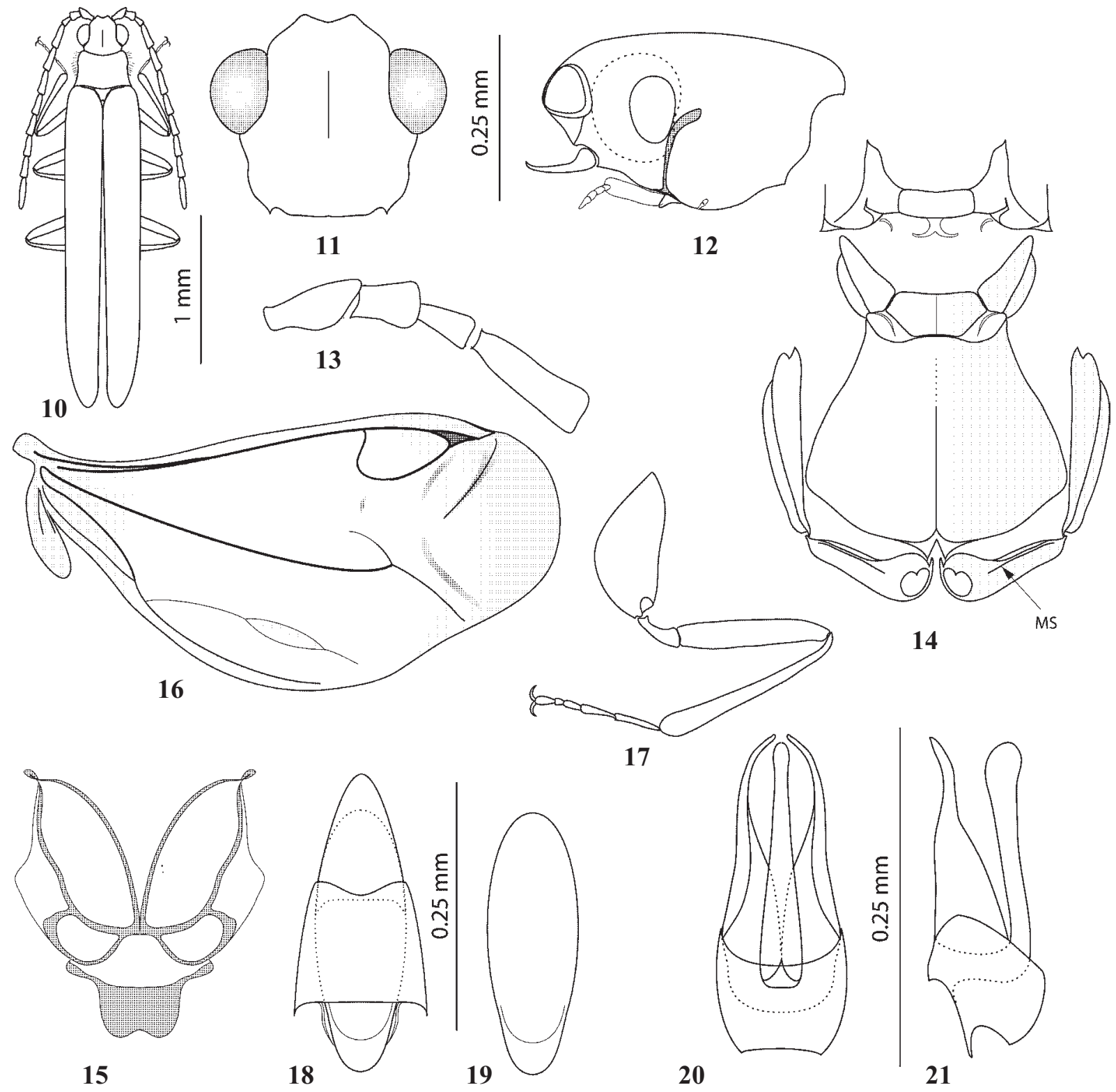

Figs 10-21. Details of Thilmanus obscurus, male: 10 - general view; 11-12 - head; 13 - antennomeres $1-4 ; 14-$ thorax; 15 mesonotum; 16 - hind wing; 17 - middle leg; 18 - genital capsule; 19 - ultimate ventrite; 20-21 — aedeagus; 14, 20 - ventral view; 10, 11, 15, 18 - dorsal view; 12, 21 - lateral view; $M S$ - meral suture [after Kazantsev, 2005, modified].

Рис. 10-21. Детали строения Thilmanus obscurus, самца: 10 - общий вид; 11-12 - голова; 13 - антенномеры 1-4; 14-грудь; 15 - среднеспинка; 16 - крыло; 17 - средняя нога; 18 - генитальная капсула; 19 - вершинный вентрит; 20-21 - эдеагус; 14, 20 - снизу; 10, 11, 15, 18 - сверху; 12, 21 - сбоку; $M S$ - меральный шов [по Казанцеву, 2005, с изменениями].

Tribe THILMANINI Kazantsev, 2005

Type genus: Thilmanus Gemminger, 1869.

DIAGNOSIS. Thilmanini is distinguishable from Euanomini tr.n., the other tribe included in the subfamily, by the simple metaventrite (Fig. 14), hind wing with anal lobe and $\mathrm{Cu}$ veins fused only to A veins (Fig. 16), elongate trochanters (Fig. 17) and short proximal apodemes of the penultimate tergite (Fig. 18).

DISTRIBUTION. The only genus classified in this tribe Thilmanus Gemminger, 1869, is registered in the Central (Corsica and Sardinia) and Western (Pyreneans) Mediterranean.
Thilmanus obscurus Baudi di Selve, 1872

(Figs 10-21)

Thilmanus obscurus Baudi di Selve, 1872: 96.

= Thilmanus fuscus Baudi di Selve, 1872: 97.

= Thilmanus longipennis Pic, 1912: 41.

MATERIAL. $5 \sigma^{7} \sigma^{7}$, Corsica (ICM and ZIN)

DISTRIBUTION. Corsica and Sardinia.

\section{Tribe EUANOMINI Kazantsev tr.n.}

Type genus: Euanoma Reitter, 1889

DIAGNOSIS. Euanomini tr.n. is readily distinguishable from the nominative tribe, Thilmanini, by the mesosternal 


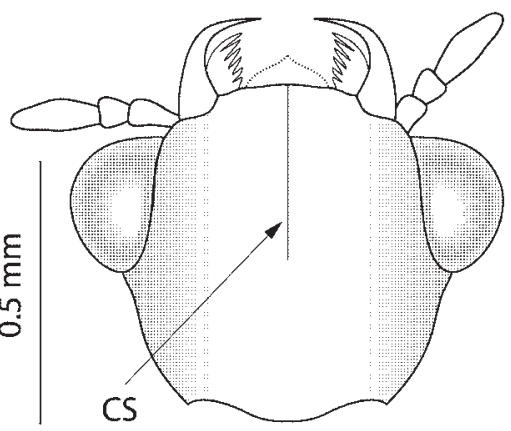

22

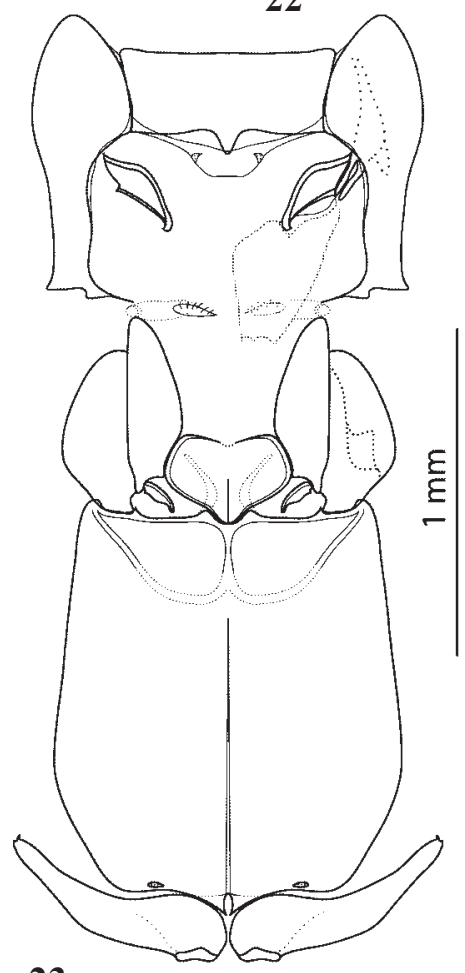

23

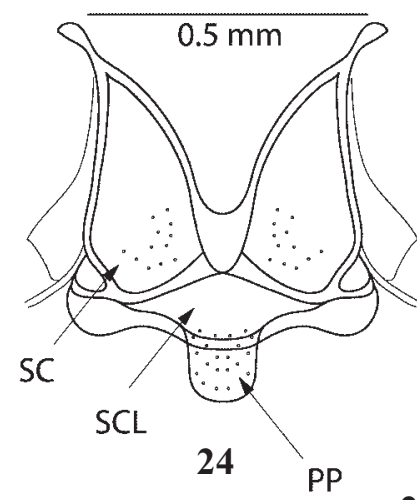

PP

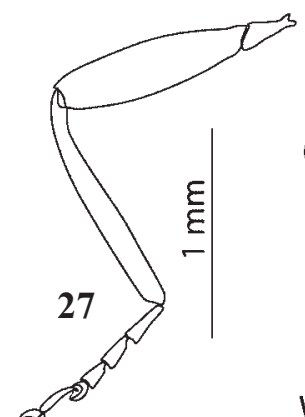

WC
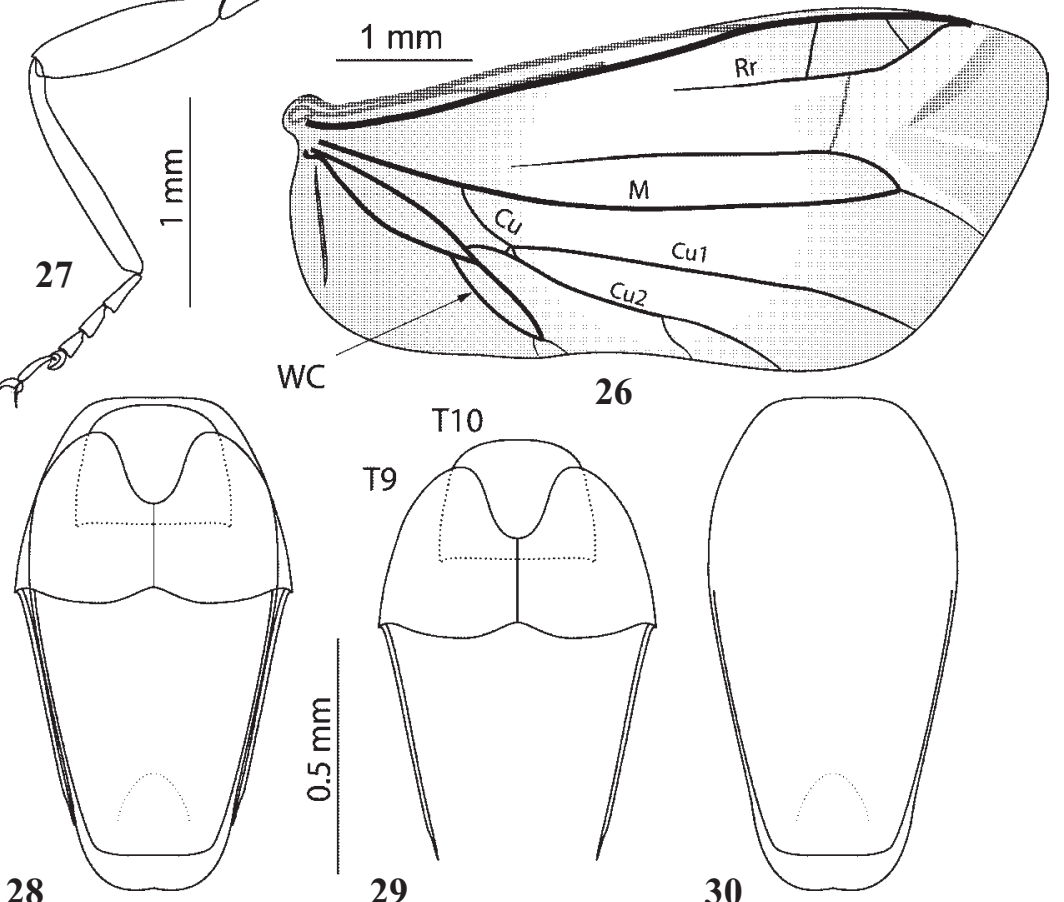

29

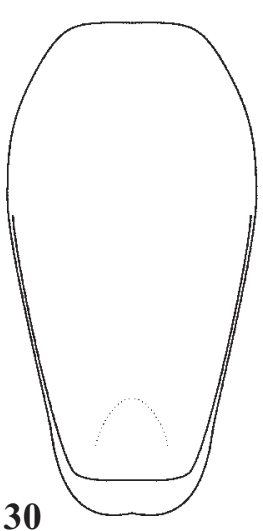

Figs 22-30. Details of Euanoma starcki, male: 22 - head; 23 - thorax; 24 - mesonotum; 25 - metanotum; 26 - hind wing; 27 middle leg; 28 - genital capsule; 29 - terminal tergites; 30 - ultimate ventrite; 23,30 - ventral view; 22, 24, 28, 29 - dorsal view; CS coronal suture; $I S$ - intrascutal suture; $P N P$ — postnotal plate; $P P$ - posterior process; $S C$ - scutum; $S C L-$ scutellum; $S S S$ scutoscutellar suture; $T$ - tergite; $W C$ — wedge cell [after Kazantsev, 2008].

Рис. 22-30. Детали строения Euanoma starcki, самец: 22 - голова; 23 - грудь; 24 - среднеспинка; 25 - заднеспинка; 26 - крыло; 27 - средняя нога; 28 - генитальная капсула; 29 - вершинные тергиты; 30 - вершинный вентрит; 23,30 снизу; 22, 24, 28, 29 - сверху; $C S$ - корональный шов; $I S$ - интраскутальный шов; $P N P$ - постнотальная пластина; $P P$ - задний отросток; $S C$ - скутум; $S C L$ - скутеллум; $S S S$ - скутоскутеллярный шов; $T$ - тергит; $W C$ - клиновидная ячейка [по Казанцеву, $2008]$.

sutures in the anterior part of the metaventrite (Fig. 23), hind wing without anal lobe and $\mathrm{Cu}$ veins connected both to $\mathrm{M}$ and A veins (Fig. 26), short trochanters (Fig. 27) and long proximal apodemes of the penultimate tergite (Fig. 29).

DISTRIBUTION. Only two genera, Euanoma Reitter, 1889 and Pseudeuanoma Pic, 1901, are attributed to the new tribe, both distributed in the Eastern Mediterranean (Greece, Turkey and the Caucasus).

\section{Euanoma starcki Reitter, 1889}

(Figs 22-32)

Euanoma starcki Reitter, 1889: 99.

MATERIAL. Caucasus, Sochi, 1912, G.Val leg.; Novorossijsk bay, 16.VI.1954, K.Arnoldi leg.; Caucasus, Tuapse distr., Geor- gievsk forestry, 21-26.VI.1954, K. Arnoldi leg.; NW Caucasus, Adygeya, env. Guzeripl, 23.I.1995, A. Gusakov leg.; NW Caucasus, Adygeya, Guzeripl, trap 1, on Abies, 22.VI-14.VII.2000, A. Bibin leg.; Sochi, $5 \mathrm{~km}$ NE Lazarevskoe, 1.VI.2008, Tsurikov leg.; Caucasian Reserve, Adygeya, Rd Guzeripl-Abago, km 3, Beech/Abies forest, 1000 m, Barber pitfall traps, 8-24.VII.2009, Chumachenko leg. (ICM, ZMMU and ZIN).

DISTRIBUTION. Russia (Northwestern Caucasus) and Abkhasia.

\section{Euanoma argonauta Kazantsev sp.n.}

(Figs 33-35)

MATERIAL. Holotype, ऽ, Georgia, Batumi, Botanical Garden, 19.V.1987, S. Kazantsev leg. (ICM). 


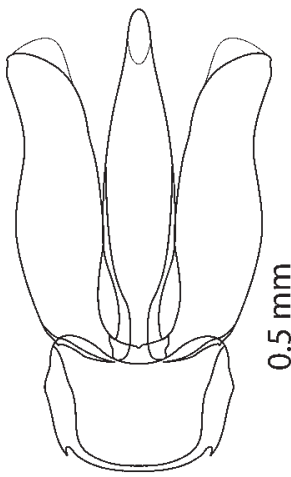

31

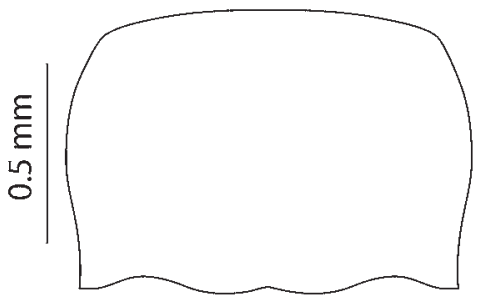

33

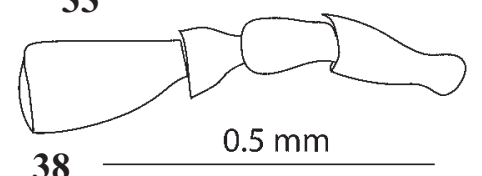

38

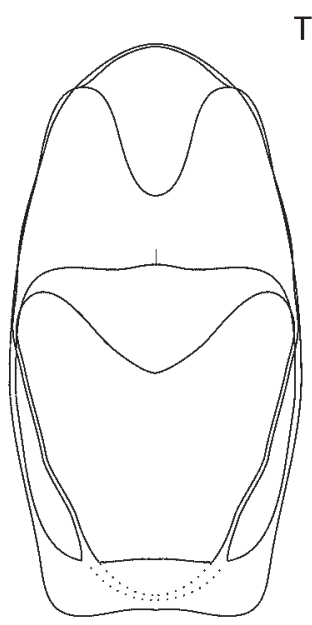

40

32

41
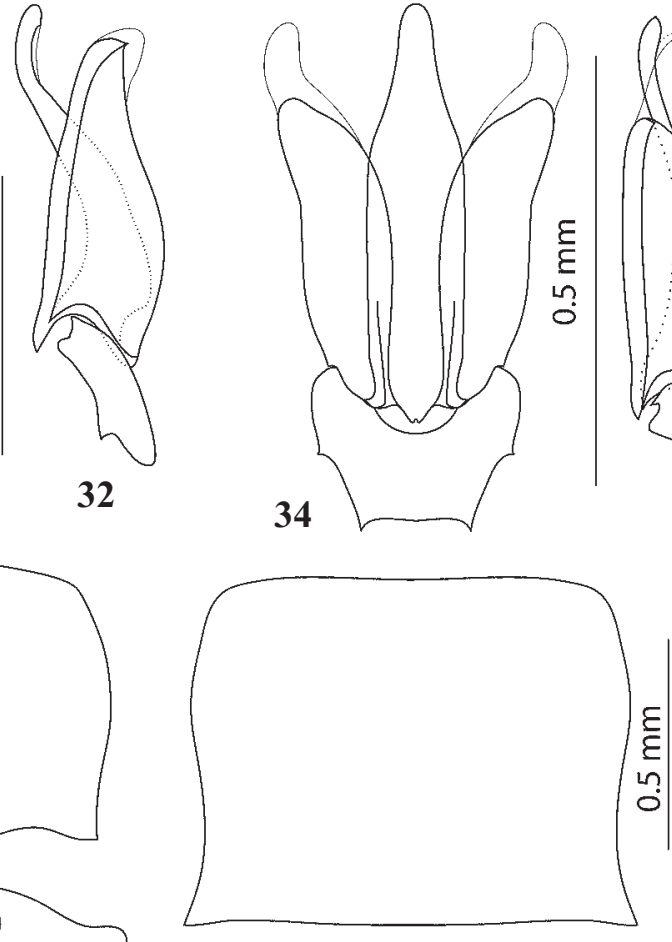

36
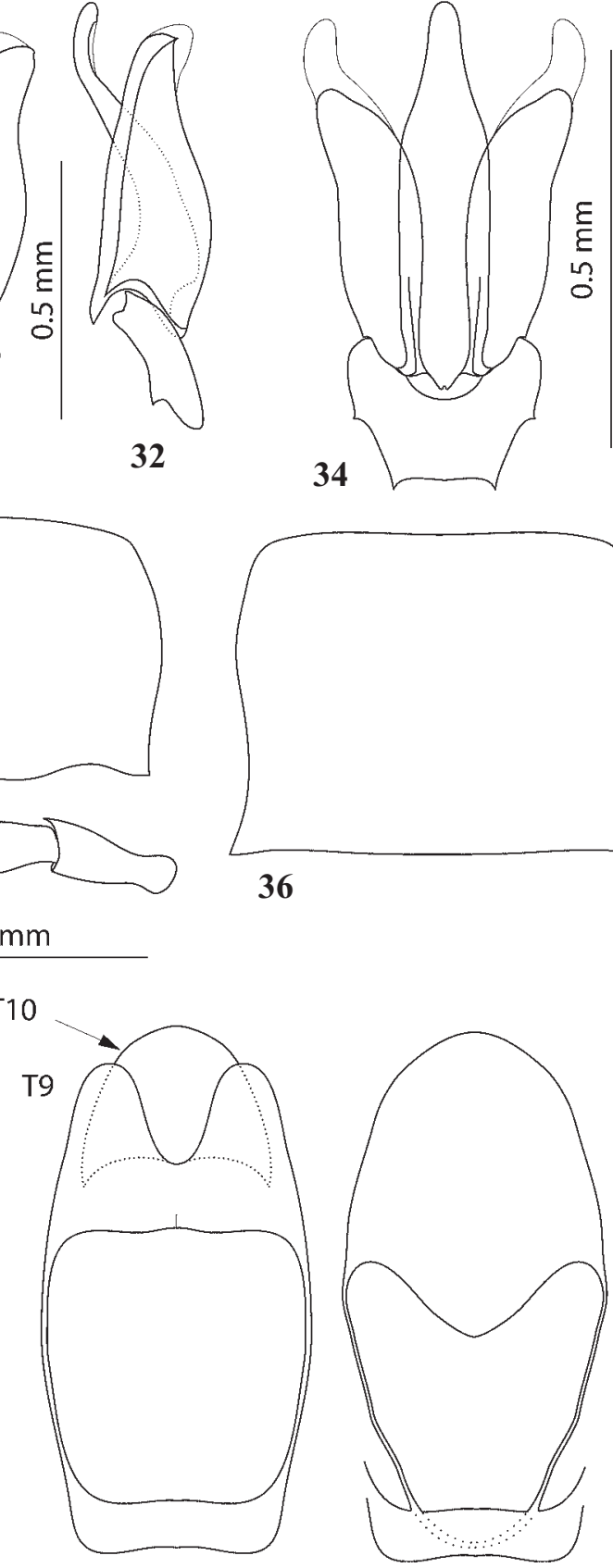

42

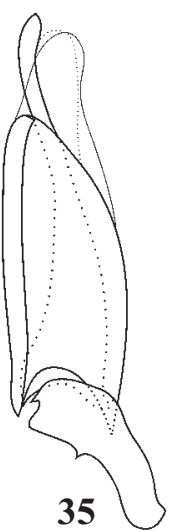

37
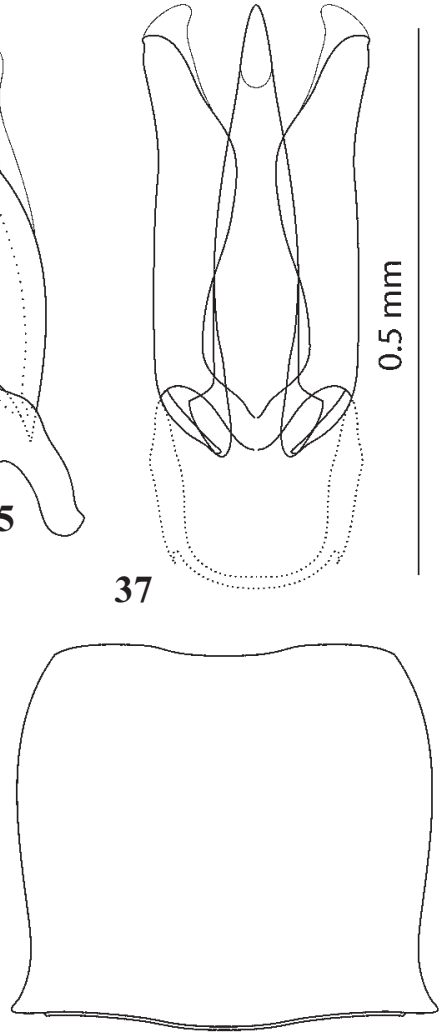

39

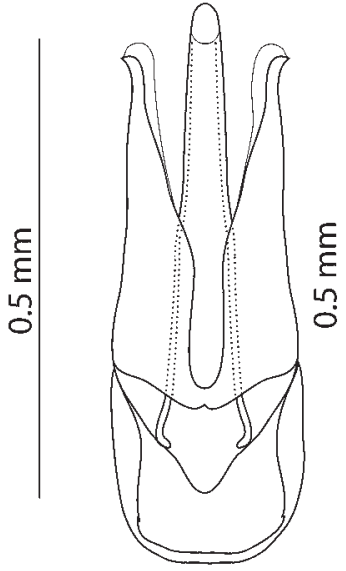

43

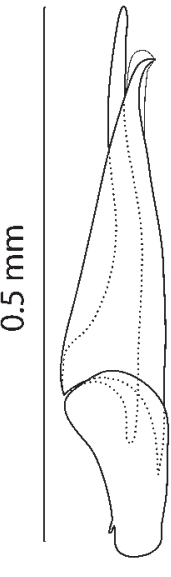

44

Figs 31-44. Details of Euanomini tr.n., males: 31-32 - Euanoma starcki; 33-35 — Euanoma argonauta sp.n.; 36-37 — Euanoma kolchica sp.n.; 38-44 - Pseudeuanoma caligo sp.n.; 38 - antennomeres 1-4; 33, 36, 39 - pronotum; 40 - genital capsule; 41 - ultimate tergites; 42 - ultimate ventrite; 31-32, 34-35, 37, 43-44 — aedeagus; 33-44 — holotypes; 42 — ventral view; 40, 41 — dorsal view; 32, 35, 44 - lateral view; $T$ - tergite.

Рис. 31-44. Детали строения Euanomini tr.n., самцов: 31-32 - Euanoma starcki; 33-35 — Euanoma argonauta sp.n.; 36-37 Euanoma kolchica sp.n.; 38-44 - Pseudeuanoma caligo sp.n.; 38 - антенномеры 1-4; 33, 36, 39 - переднеспинка; 40 - генитальная капсула; 41 - вершинные тергиты; 42 - вершинный вентрит; 31-32, 34-35, 37, 43-44 - эдеагус; 33-44 - голотипы; 42 - снизу; 40, 41 - сверху; 32, 35, 44 - сбоку; $T$ - тергит.

DESCRIPTION. Male. Dark brown; three basal antennomeres, palps, hind angles of pronotum, scutellum and legs yellowish brown. Eyes small, interocular distance ca. 3 times greater than eye radius. Antennae filiform, attaining to elytral third, with antennomere 3 subequal in length to antennomere 2 and combined subequal in length to antennomere 4.
Pronotum transverse, 1.5 times wider than long, slightly convex anteriorly and sinuate before small and almost straight hind angles (Fig. 33), densely punctured near margins, nearly glabrous at disk. Scutellum small, elongate, almost parallelsided, rounded at apex.

Elytra moderately long, ca. 2.7 times longer than wide at humeri, slightly widening posteriorly; with inconspicuous 

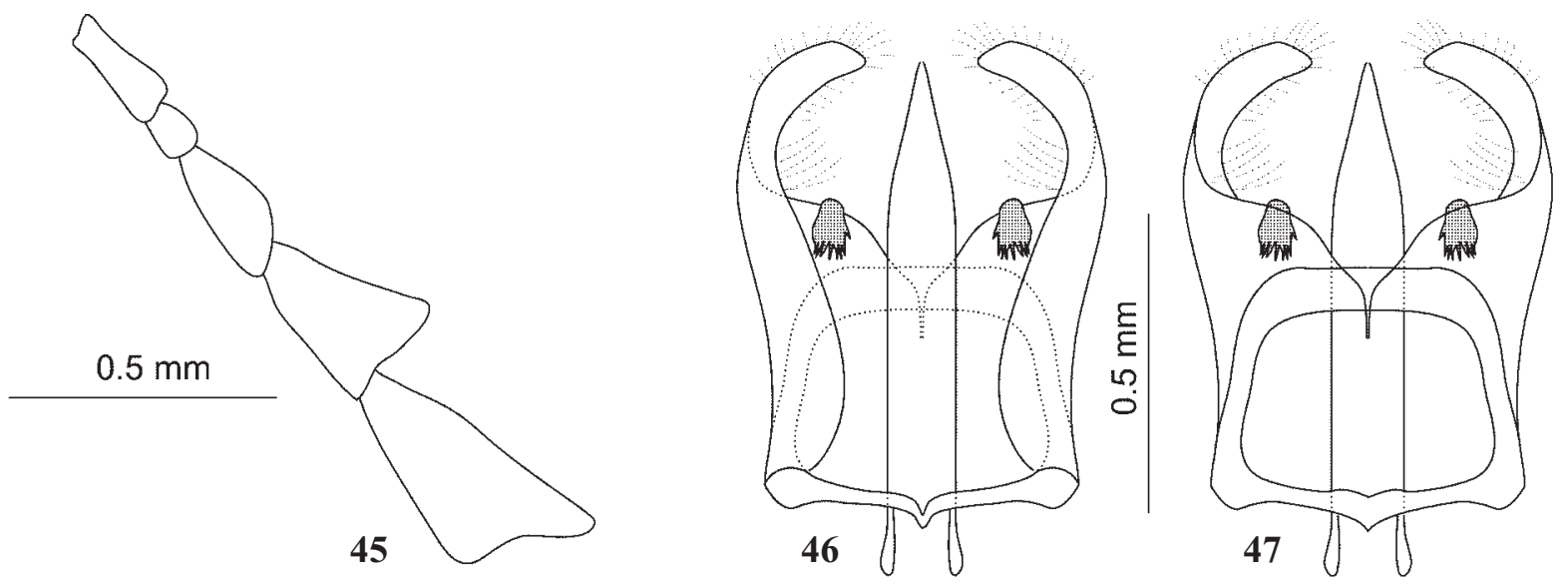

T10

$0.5 \mathrm{~mm}$
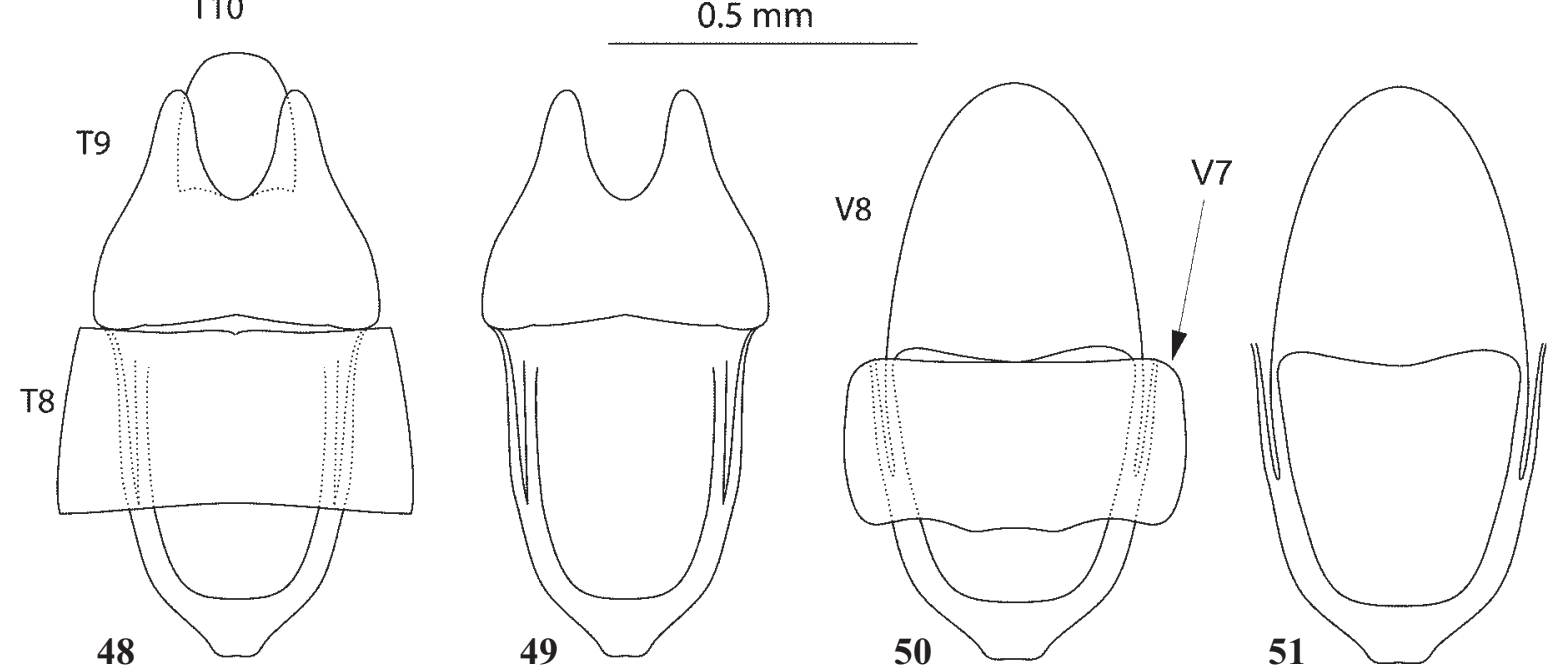

Figs 45-51. Details of Omethidae and Omalisidae: 45-47 — Drilonius flavipennis sp.n., holotype; 48-51 - Omalisus fontisbellaquaei; 45 - antennomeres 1-5, 46-47 — aedeagus; 48, 50 — genital capsule; 49 — tergite 9; 51 — ventrite 8; 46, 50, 51 — ventrally, 47, 48, 49 — dorsally; $T$ — tergite; $V$ — ventrite [Figs 48-51 after Kazantsev, 2007, modified].

Рис. 45-51. Детали строения Omethidae and Omalisidae: 45-47 - Drilonius flavipennis sp.n., holotype; 48-51 - Omalisus fontisbellaquaei; 45 - антенномеры 1-5, 46-47 - эдеагус; 48, 50 - генитальная капсула; 49 — тергит 9; 51 - вентрит 8; 46, 50, 51 - снизу, 47, 48, 49 - сверху; $T$ - тергит; $V$ - вентрит [рис. 48-51 по Казанцеву, 2007, с изменениями].

longitudinal striae and obscure transverse reticulation, with sparse tiny tubercles; relatively long pubescence scarce and erect.

Aedeagus with bottle-shaped median lobe and relatively short sclerotized portion of parameres, hardly attaining to three fourths of median lobe (Figs 34-35).

Length: $4.9 \mathrm{~mm}$. Width (humerally): $1.45 \mathrm{~mm}$.

Female. Unknown.

DIAGNOSIS. Euanoma argonauta sp.n. differs from all congenerics by the relatively short sclerotized portion of parameres, which are no longer than three fourths of median lobe (Figs 34-35). Additionally, the new species is easily distinguishable from $E$. starcki by the uniformly dark brown elytra and from E. elongata Pic, 1932 by the more transverse pronotum (Fig. 33).

ETYMOLOGY. The name of the new species is derived from the Latin for "Argonaut", alluding to the proximity of the type locality to the Black Sea shore where the legendary Argonauts landed in search for the Golden Fleece.

\section{Euanoma kolchica Kazantsev sp.n.}

(Figs 36-37)

MATERIAL. Holotype. $\sigma^{7}$, Georgia, Borzhomi, 9.VI. (19)37, S. Nikulin leg. (ICM).

DESCRIPTION. Male. Dark brown; tibial apices and tarsi yellowish brown.

Eyes small, interocular distance ca. 4.2 times greater than eye radius. Antennae filiform, short, attaining to elytral fourth, with antennomere 3 subequal in length to antennomere 2 and combined subequal in length to antennomere 4.

Pronotum transverse, 1.35 times wider than long, slightly convex anteriorly and sinuate before small and almost straight hind angles (Fig. 36), densely punctured near margins, nearly glabrous at disk. Scutellum small, elongate, almost parallelsided, rounded at apex.

Elytra moderately long, ca. 2.75 times longer than wide at humeri, slightly widening posteriorly; with inconspicuous longitudinal striae punctatae and obscure transverse reticulation, with sparse tiny tubercles; relatively long pubescence scarce and erect. 
Aedeagus narrow, with relatively broad proximal portion of the median lobe (Fig. 37).

Length: $5.3 \mathrm{~mm}$. Width (humerally): $1.5 \mathrm{~mm}$.

Female. Unknown.

DIAGNOSIS. Euanoma kolchica $\mathbf{s p . n . ~ i s ~ s i m i l a r ~ t o ~ E . ~ e l o n - ~}$ gata, known only from one specimen from Ossetia [Kundrata \& Bocák, 2007], differing by the glabrous pronotal disk, uniformly dark brown antennae and mostly dark brown legs, with yellowish brown tarsi and tibial apices and by the broader proximal portion of the median lobe of the aedeagus (Fig. 37).

ETYMOLOGY. The name of the new species is derived from "Kolchis", the ancient Greek name for the country where the type specimen was collected.

\section{Pseudeuanoma caligo Kazantsev sp.n.}

(Figs 2, 38-44)

MATERIAL. Holotype. $0^{7}$, S Turkey, East of Alanya, $850 \mathrm{~m}, 7-$ 8.VI.2000, S. Kazantsev leg. (ICM).

DESCRIPTION. Male. Uniformly dark brown.

Eyes moderately large, interocular distance ca. 2.3 times greater than eye radius. Antennae filiform, attaining to elytral half (Fig. 2), with antennomere 3 subequal in length to antennomere 2 and combined subequal in length to antennomere 4 (Fig. 38).

Pronotum almost quadrate, slightly medially emarginate anteriorly and sinuate before small, but acute hind angles (Fig. 39), sparsely punctured, denser near margins. Scutellum small, elongate, almost parallel-sided, truncate at apex.

Elytra long, ca. 3 times longer than wide at humeri, slightly widening posteriorly; densely tuberculose; moderately long pubescence scarce and erect (Fig. 2).

Genital capsule consisting of tergites 9 and 10 and ventrite 8 , tergite 9 and ventrite 8 with closed proximally lateral apodemes; lateral apodemes of ventrite 8 proximally fused to proximal portion of tergite 9 (Figs 40-42). Aedeagus with distally narrowing median lobe and outwardly hooked apices of straight parameres; phallobase with minute lateral apodemes (Figs 43-44).

Length: $4.4 \mathrm{~mm}$. Width (humerally): $1.0 \mathrm{~mm}$.

Female. Unknown.

DIAGNOSIS. Pseudeuanoma caligo sp.n. is distinguishable from P. obscura Pic, 1901, also from Turkey, by the somewhat smaller eyes and outwardly hooked apices of elongate parameres of the aedeagus (Figs 43-44).

ETYMOLOGY. The name of the new species is derived from the Latin for "darkness", alluding to its coloration.

\section{Family OMETHIDAE}

\section{Drilonius flavipennis Kazantsev sp.n.} (Figs 45-47)

MATERIAL. Holotype. $\sigma^{7}$, China, Yunnan, S Dali, Xiaguan, 2370 m, 29.VII.2002, S. Murzin leg. (ICM); paratypes, 5 우, same label (ICM).

DESCRIPTION. Male. Black; elytra uniformly ochre; head behind eyes with rufous spot.

Eyes small, interocular distance ca. 3.6 times greater than eye radius. Antennae serrate, attaining to elytral two thirds, with antennomere 32.5 times longer than antennomere 2 and 1.1 times shorter than antennomere 4 (Fig. 45).

Pronotum transverse, ca. 1.6 times wider than long, broadly convex anteriorly and posteriorly, with almost parallel slightly convex sides. Scutellum elongate, parallel-sided, slightly emarginate at apex.

Elytra long, ca. 3.1 times longer than wide at humeri, almost parallel-sided, only slightly concave at sides; all four longitudinal costae reaching elytral apices; interstices with regular rows of transverse rectangular cells; pubescence short and relatively dense.

Aedeagus with elongate distally curved parameres; dorsal blade triangularly emarginate, with a pair of brush-bearing projections (laterophyses) (Figs 46-47).

Female. Similar to male, but antennae slightly less serrate. Length: 4.9-5.4 mm. Width (humerally): 1.45-1.6 mm.

DIAGNOSIS. Drilonius flavipennis sp.n. is readily distinguishable from all congenerics by the uniformly ochre elytra and long curved parameres and other details of the aedeagus (Figs 46-47).

ETYMOLOGY. The name of the new species is derived from the Latin for "with fulvous wings", alluding to the coloration of its elytra.

\section{Checklist of the subfamily Thilmaninae}

$$
\text { Subfamily THILMANINAE Kazantsev, } 2005
$$

Tribe THILMANINI Kazantsev, 2005

Genus Thilmanus Gemminger, 1869

Thilmanus Gemminger, 1869: 1683.

Type species Thilmanus obscurus Baudi di Selve, 1872. laticeps Pic, 1913: 185. France (Pyreneans).

= latipes Bocak, 2007: 211 [lapsus calami].

obscurus Baudi di Selve, 1872: 96. France (Corsica) and Italy

(Sardinia).

= fuscus Baudi di Selve, 1872: 97.

= longipennis Pic, 1912: 41 .

\section{Tribe EUANOMINI Kazantsev tr.n.}

Genus Euanoma Reitter, 1889

Euanoma Reitter, 1889: 98 .

Type species Euanoma starcki Reitter, 1889. argonauta Kazantsev sp.n. Georgia.

curvata Kundrata et Bocak, 2007: 530. Turkey. elongata Pic, 1932: 2. Central Caucasus (Ossetia). graeca Pic, 1901: 49 (Phaeopterus). Greece. kolchica Kazantsev sp.n. Georgia.

marketai Kundrata et Bocak, 2007: 433. Turkey. semitestacea Pic, 1907: 153 (Pseudeuanoma). Turkey. starcki Reitter, 1889: 99. Northwestern Caucasus (Russia and Abkhasia).

svihlai Kundrata et Bocak, 2007: 434. Turkey.

\section{Genus Pseudeuanoma Pic, 1901}

Pseudeuanoma Pic, 1901: 33.

Type species Pseudeuanoma obscura Pic, 1901. caligo Kazantsev sp.n. Southern Turkey.

jonica Pic, 1901: 49. Greece (Kefalonia and Zakynthos)

= semiobscura Pic, 1901: 49 .

= subimpressa Pic, 1901: 74 .

obscura Pic, 1901: 33. Turkey.

reitteri Pic, 1901: 49. Greece (Kerkyra and Zakynthos).

\section{Discussion}

Certain characters of all or some thilmanines that are hereby classified in Drilidae, e.g., the medially divided mesoventrite with more or less straight anterior margin, mesosternal sutures of the metaventrite (Figs 14, 23) or the latero-proximal apodemes of the phallobase and outwardly hooked apices of parameres of Euanoma or 
Pseudeuanoma (Figs 22-30,37,43), are shared by Omalisus, the type genus of Omalisidae [Kazantsev, 2007]. Also, the structure of the genital capsule of Pseudeuanoma (Figs 40-42) is fairly similar to that of Omalisus (Figs 48-51), with their penultimate tergite and ultimate sternite proximally fused together.

These shared morphologies seem to compromise the monophylies of the families. However, the omalisids appear to be clearly differentiated from the drilids by such autapomorphies, as the robust tentorium with conspicuous tentorial bridge and much heavier sclerotized elytra coadapted both with thorax and abdomen, the sclerotized epipleuron and sutural flange attaining to elytral apices - the above mentioned shared traits probably representing symplesiomorphies of the two lineages.

Nevertheless, it is evident that the relationships between Omalisidae and Drilidae still need further study, an important part of which would be the study of drilid genera other than Drilus and the thilmanines.

ACKNOWLEDGEMENTS. It is my pleasant duty to express gratitude to the late Dr. G.S. Medevedev (Zoological Institute, S-Petersburg) and Dr. N.B. Nikitsky (Zoological Museum of Moscow University) for the possibility of examining the Cantharoidea collections under their care. My special thanks are due to Prof. K.V. Makarov (Moscow) for his help with the colour photos of Cimbrion nigricorne and Pseudeuanoma caligo sp.n.

\section{References}

Bocák L. \& Bocáková M.1990. Revision of the supergeneric classification of the family Lycidae (Coleoptera) // Polskie pismo entomologiczne. Vol.59. No.4. P.623-676.

Bocák L. \& Brlik M. 2008. Revision of the family Omalisidae (Coleoptera, Elateroidea) // Insect Systematics \& Evolution. Vol.39. P.189-212.

Crowson R.A. 1972. A review of the classification of Cantharoidea (Coleoptera), with the definition of two new families, Cneoglossidae and Omethidae // Revista de la Universidad de Madrid. Vol.21. P.35-77.

Dolin V.G. 2000. [A role of larval and wing venation characters in the systematics of Elateroidea (Coleoptera)] // Readings in memory of N.A. Cholodkovsky. Lecture at the $52^{\text {nd }}$ annual reading, April 1, 1999, S. Petersburg: ZIN. 50 pp. [in Russian].

Geisthardt M. 1977. Redeskription der weiblichen Imago von Homalisus fontisbellaquei Geoffroy, 1762 (Coleoptera: Homalisidae) // Mitteilungen des Internationalen Entomologischen Vereins. Bd.3. H.7. S.113-119.

Kazantsev S.V. 2005. Morphology of Lycidae with some considerations on evolution of the Coleoptera // Elytron. Vol.1718 (2004) et Coleopterological Monographs. Vol.3. P.73248.

Kazantsev S.V. 2008. [Comparative morphology of the genus Euanoma Reitter, 1889 (Coleoptera, Drilidae)] // Russian Entomological Journal. Vol.16 (for 2007). No.4. P.439-449 [in Russian with English summary].

Kazantsev S.V. 2009. Leptolycini of Puerto Rico (Coleoptera, Lycidae) // Russian Entomological Journal. Vol.18. No.2. P.87-95.

Kundrata R. \& Bocák L. 2007. A revision of Euanoma and Pseudeuanoma (Coleoptera: Drilidae) // Annales Zoologici PAN. T.57. No.3. P.427-441.

Lawrence J.F. \& Newton A.F., Jr. 1995. Families and subfamilies of Coleoptera (with selected genera, notes, references and data on family-group names) // J. Pakaluk \& S.A. Slipinski (eds.). Biology, phylogeny, and classification of Coleoptera: Papers celebrating the $80^{\text {th }}$ birthday of R.A. Crowson. Vol.2. Warszawa: Muzeum i Instytut Zoologii PAN. P.779-1006.

Medvedev L.N. \& Kazantsev S.V. 1992. [A new subfamily and a new genus of Lycidae from Southeast Asia] // L.N. Medvedev (ed.). Systematics and ecology of insects of Vietnam. Moscow: Nauka. P. 55-60[in Russian]. 